\title{
Article \\ The Influence of Political Capital on Peasants' Migration Behavior and Its Implications
}

\author{
Haojing Shen ${ }^{1}$, Yan Song ${ }^{2}$, Changchun Feng ${ }^{3, *}$ and Zhengying Shan ${ }^{3}$ \\ 1 Department of Public Policy and Management, University of Science and Technology Beijing, \\ Beijing 100083, China; shenhj@ustb.edu.cn \\ 2 Department of City and Regional Planning, University of North Carolina at Chapel Hill, \\ Chapel Hill, NC 27599, USA; ys@email.unc.edu \\ 3 College of Urban and Environmental Science, Peking University, Beijing 100871, China; \\ zhengyingshan@pku.edu.cn \\ * Correspondence: fcc@urban.pku.edu.cn; Tel.: +86-10-6233-2425
}

Citation: Shen, H.; Song, Y.; Feng, C.; Shan, Z. The Influence of Political Capital on Peasants' Migration Behavior and Its Implications. Land 2021, 10, 1363. https://doi.org/ 10.3390/land 10121363

Academic Editor: Qiujie Shi

Received: 12 November 2021 Accepted: 7 December 2021 Published: 10 December 2021

Publisher's Note: MDPI stays neutral with regard to jurisdictional claims in published maps and institutional affiliations.

Copyright: (c) 2021 by the authors. Licensee MDPI, Basel, Switzerland. This article is an open access article distributed under the terms and conditions of the Creative Commons Attribution (CC BY) license (https:// creativecommons.org/licenses/by/ $4.0 /)$.

\begin{abstract}
This study examined the influence of political capital on the migration behavior of peasant households in China's equitable urbanization. While existing research has proven that political capital can increase the wages of migrant workers, leading to a higher possibility of their ruralto-urban migration, the direct impact of political capital on migration behavior has not received sufficient attention. As China is one of the largest emerging economies, the impact of political capital on the economy and political transformation is typical. This paper reports a survey of 1120 farmer households from Xinxiang, a traditional agricultural area in central China. Using a binary logit model to test whether peasant households will migrate and a multinomial logit model to test where they will migrate to, this study examined whether political capital had a significant influence on the migration behavior of peasant households. The results suggest that the peasant households with political capital have a higher possibility of moving to urban areas, even though there is a better habitational option, namely, a new village in the local rural area. This suggests that reducing the difference in the political capital of migrants through policy propaganda and other methods is an efficient and effective way to achieve and improve equitable access to urbanization.
\end{abstract}

Keywords: migration behavior; urbanization; equitable access; political capital; new village; binary logit model; multinomial logit model; traditional agricultural areas; China

\section{Introduction}

In the process of China's transition to a socialist market-oriented economy, along with rapid urbanization, a large number of farmers have migrated to cities to work or live; however, whether each peasant has equitable access to urbanization is still a critical issue that needs to be studied. Ensuring that disadvantaged farmers have the opportunity and ability to make a fair choice in migration can promote inclusive urbanization. Researchers have always believed that economic factors are the main driver of migration behavior; however, economic activities are inevitably subject to the restrictions of political actors [1] Farmers who lack political capital are a kind of disadvantaged group, and they should be given full attention in relation to fair and inclusive urbanization. As a transitional economy, after the urbanization rate exceeded $50 \%$ in 2011, the Chinese Government adopted a series of measures, such as household registration reform, to promote urban-rural coordination and strengthen equitable access to urbanization. At the same time, during the 18th National Congress of the Chinese Communist Party in 2012, the party accelerated reforms in strengthening both public participation and administrative supervision to improve governance abilities. Changes in China's political and economic situation have affected political factors related to economic activities, making migration decisions more significant [2,3]. As a result of the close relationship between political capital and other forms of capital, such as 
human capital and economic capital [1], the influence of political capital on the migration behavior of peasants has become increasingly apparent in urbanization. Particularly, large political capital means more jobs in a local region [4]. Thus, in the process of equitable urbanization, political capital is now an essential factor affecting peasants' equitable access to urbanization, deciding whether they migrate and where they migrate to. This is the focus of this study.

Existing research has established theories that attempt to explain rural-to-urban migration from the perspectives of efficiency, human capital, and economic or social factors. For example, the push-pull theory, the migration transition theory, and the dual labor market theory argue that the urban-rural income schism created by the urban-rural dual economic structure is the main reason for peasants' migration to cities. Peasants have a considerable desire to live in cities because of their better employment opportunities, higher incomes, better medical care, and social security. The new economics of labor migration theory argue that migration is a result of peasant families' decision making, and maximizing income is the primary consideration in mitigating migration risks. However, while economic factors have been proven to be the most important factor affecting migration [5], from the perspective of peasants' micro-behavior, political capital also affects their employment opportunities and income [3]. Although market transformation can reduce this impact, it is still influential in rural areas [6]. Therefore, political capital impacts migration behavior, especially for farmers who want to work and live in cities. Unfortunately, the literature in this area still requires supplementation. Our research focuses on the role of political capital in the migration behavior of peasant households and equal access to urbanization.

For such theoretical and practical issues, the Chinese case is representative. Urbanization is a universal trend throughout the world. In recent decades, tens of thousands of rural-to-urban migrant workers have supported China's rapid urbanization process [7] and provided essential case areas for theoretical and practical research on migration behavior. In addition, China is a fast-growing developing country transitioning from a planned management system to a socialist market economic system. Additionally, its political and economic environment is changing. On the one hand, the Chinese Government has gradually implemented household registration reform, promulgated several measures to improve the welfare of migrants, and implemented rural revitalization strategies to promote rural development. On the other hand, government functions and state governance capabilities have gradually improved. After the 18th National Congress of Chinese Communist Party in 2012, the Chinese Government increased its anti-corruption efforts, accelerated the decentralization of administration, strengthened the legal system, and toughened up the administrative supervision mechanism. Therefore, China is a more than suitable country in which to study the influence of political capital. There are three reasons why rural China is appropriate. First, in rural China's grassroots autonomy, party members, and cadres play an important role in policy implementation. Second, traditional agricultural areas can reflect China's fundamental problems because agriculture civilization is deeply rooted in Chinese culture. Third, in response to rural decay, the Chinese Government has created systematic policies. In summary, China, especially China's traditional agricultural areas, is a typical case in the study of political capital's influence on migration behavior, and it is also a helpful template for other countries and regions in the world.

This paper consists of four sections. First, a theoretical discussion is presented, comprising a literature review on the influencing factors of migration behavior. This is followed by a description of the methods of this research, including research design, the study area, sampling methods, and the model used. Next, the results and interpretations are presented in three parts: the results of the binary logit model, the multinomial logit model, and the explanation of political capital. Finally, a summary and discussion of the main findings of this study are presented, addressing the research questions, with a focus on the influence of political capital on migration behavior. 


\section{Literature Review}

In order to explore the influence of political factors on migration behavior, this paper first reviews the research on the influencing factors of migration behavior and then reviews the changes in the policy environment in the case area.

\subsection{The Factors for Migration Behavior}

Farmers must fully consider their household's actual situation, such as the need to promote household development and reduce overall risks faced by their families in relation to staying or migrating. As such, new labor migration economists argue that the household is a crucial element in migration decisions [8-11]. Therefore, the following summarizes the factors affecting migration behavior from the perspective of the household.

Much previous research has studied the factors affecting migration behavior, primarily focusing on human capital and economic capital. On the one hand, human capital directly affects the migration choice of migrants; this has been widely proven [12]. Migrant peasants with better education, training background, and technological skills are more likely to occupy better jobs and earn higher wages in the urban environment. The previous literature has exacted relevant research on some indicators that reflect human capital, such as education level, migrant employment rate, etc. [11]. Similarly, China's research verifies that peasants with high human capital have greater motivation for migration behavior $[13,14]$. On the other hand, higher income expectations and a huge wage gap between rural and urban areas are the most important factors motivating peasant to move to the industrial sector and cities $[5,15]$. As a result of the significant and important impacts of the income gap, peasants still want to work in certain places to obtain high wages [16]. In this situation, rural laborers utilize all available resources and advantages working in urban areas, and return to the countryside when possible [11,17]. Previous studies have shown that the determinants of migration decisions include education, income gap, rural industry, and regional economic development $[7,18,19]$.

In addition, many studies suggest that political capital, such as village cadre status or Chinese Communist Party (CCP) membership, has a profound impact on rural peoples' migration decisions $[2,3,20]$. In China, rural-to-urban migration was strictly controlled by the household registration system, called Hukou, until 1978. This policy is linked to urban welfare through Hukou indicators. After 1978, in order to encourage labor mobility, the Hukou policy was relaxed slightly. Shortly after, the phenomenon of migrant rural laborers appeared, with migration largely focused on metropolises [21]. However, the labor market in China is not fully developed, and the flow of labor is still subject to many restrictions [22,23]. Village cadre members have better information about employment opportunities and are in better positions to make recommendations for family members thanks to their influence on village or township enterprises, which discourages them from engaging in occupations that require migration $[4,24,25]$. Party membership and cadre status influence peasants' acceptance of new policies and keep pace with new changes [24,26]. To some extent, political capital has accumulated human capital and transferred it into economic capital [1]. Furthermore, when the off-farm population (migrants and local off-farm workers) is divided into wage laborers and entrepreneurs, local power works differently in each case. Being a cadre family has little impact on whether a wage worker stays local or migrates, but entrepreneurs with political connections are more likely to stay in the local area [27].

Previous studies have already proved the importance of human capital and economic capital. The influence of political capital on migration behavior has not received enough attention, even though the role of political capital in increasing income and the role of income in rural-to-urban migration behavior has been confirmed [3.5]. China, a developing country with rapid economic growth, has actively promoted a transition to a socialist market economic system while vigorously developing urban areas and striving to modernize governance capabilities. Hence, its political and economic environment has undergone tremendous changes. China's rural areas are the "village self-government 
organizations under the leadership of the party". As such, in rural China, the political capital referred to as "Chinese Communist Party Membership" and "Cadre in village self-government organizations" may contribute to decision to migrate, but it nevertheless requires greater examination. In summary, China's transitional economy is an important reference for many developing countries that are rapidly urbanizing and improving their governance capacities.

\subsection{Changes in Policies Related to the Migration of Peasants}

China's rapid urbanization occurred in a historical transitional period from a planned economic system to a socialist market economic system. The political and economic environment of migration has undergone tremendous changes over the last 40 years. The Chinese Government has promoted various reforms; for peasant migration, the most influential ones are household registration reform and related policy changes in rural development.

The household registration system can be regarded as the "invisible wall" between urban and rural areas as a result of China's binary structure [28]. The strict household registration management before the reform and opening-up is not suitable for the transition period. The transformation of the market economy has increased the demand for labor in cities, and the urban-rural economic gap has widened even further, stimulating the demand for labor in the cities [29]. In this context, the household registration system began loosening. Farmers were gradually allowed to settle down in small towns and temporary residence permits were issued for migrant workers entering towns. As a result, the number of migrants increased by $10 \%$ annually from 1989 to 1995 [30]. After the beginning of the 21st century, the main direction of the household registration system reform was to encourage and guide labor mobility to promote urban-rural integration [29]. There are four important nodes of this. The first is that, in 2001, hukou management in small towns was relaxed, and the restrictions on settling in small towns were eased. Second, in 2009, the residence permit system originating in Shanghai was proposed and spread rapidly across the whole country. Third, in 2012, the 18th National Congress of the Chinese Communist Party established a process of "accelerating the reform of the household registration system and promoting the urban residency of rural migrant workers in an orderly manner." Finally, in 2016, agricultural transfer populations were allowed to settle where they were, except for in several megacities. Guo (2019) believes that the reform of the household registration system entered a new era of "new urbanization and rural revitalization strategy to deepen urban-rural integration" in 2012 [31].

The problems faced by rural areas and peasants are the most important issues for the Chinese Government. The "socialist new countryside construction" policy proposed by the Central China Government in 2006 is a comprehensive policy to promote rural development [32]. There are two important events in rural China related to this policy: (1) New Village. Affected by household registration system reform, the increase in ruralto-urban migration has caused villages in rural China to hollow out, yet the scale of per capita land use in rural areas has continued to increase [33]. In order to cope with new countryside construction, a rural land comprehensive improvement project of the cultivated land and house sites needs to be carried out in a timely manner [34]; "bottom-up" public participation is important in this progress [35]. A real-life example shows that public opinion plays an important role in this bottom-up activity to promote rural development, with new village construction as its core [36]. Public opinion, public participation, and cadre performance and evaluation are important for promoting the effective implementation of this policy [32,36]. (2) Township Enterprises. More importantly, the development of township enterprises has a major impact on the economy of rural areas. In the 1980s, township enterprises that originated from "community enterprises (shedui qiye" became the main force in the transformation of China's socialist market economic system, absorbing a large amount of surplus agriculture labor under the urban-rural dual system due to the surplus in the economic output capacity [31,37]. Township enterprises developed rapidly between 1984 and 1991, but they entered a period of stagnation from 1992 to 
1996 [37]. Due to the impact of globalization and the increase in transaction costs of township enterprises, the development of township enterprises faces increasingly intense market competition [37,38]. Meanwhile, as a result of the household registration system reform, restrictions on immigration between rural and urban areas were lifted, which further promoted migration to cities. This also led to a decline in township enterprises in the late 1990s [37].

\section{Data and Methodology}

\subsection{Research Design}

As seen from the literature review, the impact of political capital on migration behavior has not received enough attention in current studies. This is despite both the significant impact of political capital on wages and employment and the significant impact of wages and employment on migration being proved in previous research. The data used in most of the previous studies of this issue are based on national survey data from the 1990s [27,39]. With China's development, the external political, economic, social, and policy environments that farmers face when making migration decisions have undergone great changes. Therefore, it is necessary to study this issue as a new turning point. Although a self-sufficient farming civilization is deeply rooted in Chinese culture, China has considerable geographical differences, especially regional differences in terms of economic structure. In order to fully understand the influence of political capital on migration behavior, it is necessary to select areas with agricultural advantages for our research. In summary, this study focuses on the impact of political capital on peasants' migration behavior, especially in the transitional period of agriculture dominated areas, to lever the gaps in existing research (see Figure 1).

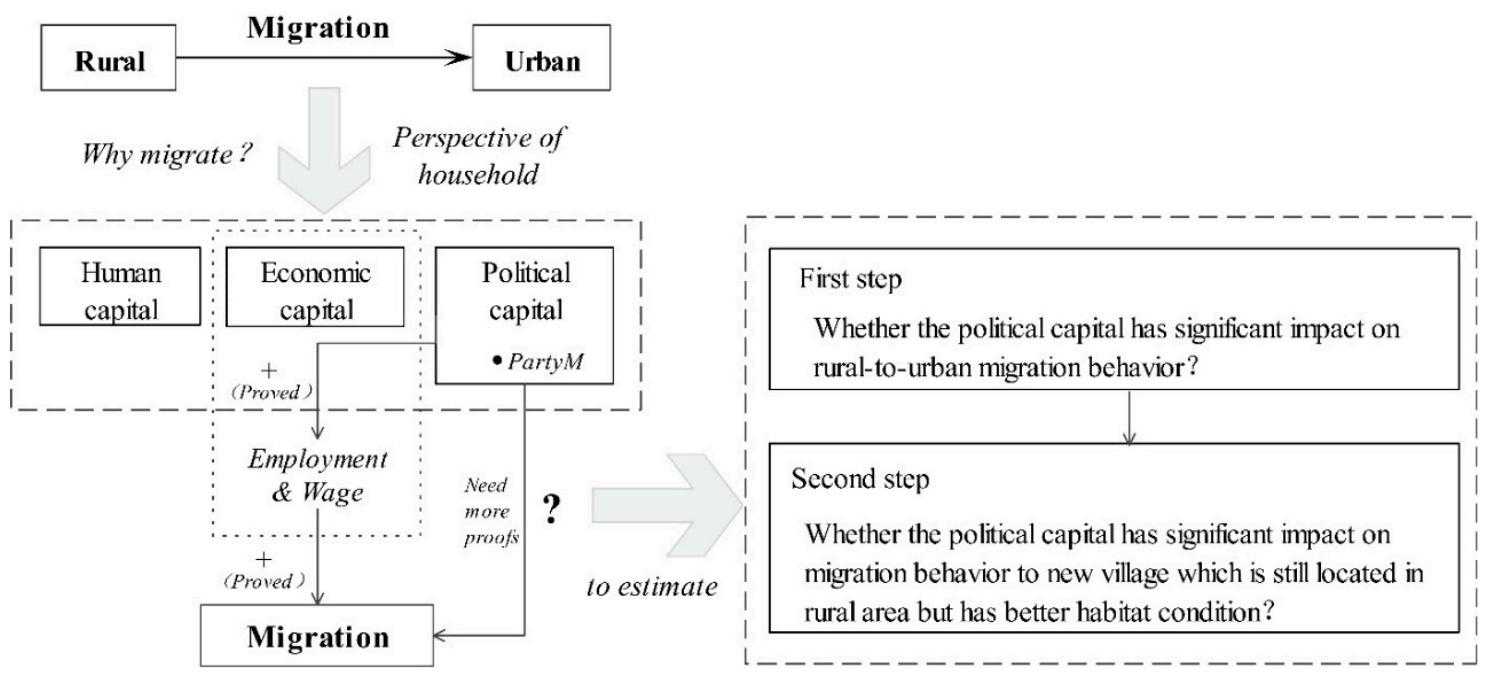

Figure 1. The design of this research.

In order to achieve this research goal, this study believes that the following two questions can be answered step by step (see Figure 1). First, does political capital play a significant role in rural-to-urban migration behavior? Second, how does political capital affect the migration options of peasants staying in local rural areas? China places great importance on promoting rural development and has implemented various beneficial policies. The emergence of new villages with better living conditions and sanitation is key for attracting peasants to migrate to rural areas. We will, therefore, focus on whether political capital has an important impact on peasants' movement to new villages.

In order to explore how political capital plays a role in peasants' migration behavior, this paper begins with peasants' micro-perspectives. This questionnaire surveyed the characteristics of peasants' households, including their human, economic, and political capital, as well as their migration behavior. In addition, in order to further analyze the migration behavior of peasants in rural areas, a question was asked to obtain the peasants' 
desire for a new village: why do you choose to settle in the new village? There were ten options, and a Likert scale was used to reflect the impact extent of each option.

\subsection{Study Area and Sampling Methods}

In order to achieve our research goals, agricultural-led areas are ideal case areas for this issue. There are three reasons behind our choice. The first is that China has undergone a great economic and social transformation led by the Chinese Communist Party. Party members and cadres play a significant leadership role in rural revitalization activities. Thus, rural China is an ideal case for studying the influence of political capital. The second important reason is that agricultural areas comprise a large sample size, making them advantageous for studying peasants' problems. The third reason is that agriculture areas are always a major source of migrant workers. Since these areas only provide minimum wage, peasants have low incomes, meaning that food production areas are the poorest in China [40,41]. Additionally, many peasants migrated to megacities after the household registration reform. Based on the reasons above, to achieve our research goal, choosing a traditional agricultural area with an established agricultural civilization is crucial. Furthermore, this can prevent certain special phenomena due to the large geographical differences when accessing national-scale data.

China is undergoing rapid development. Unlike previous research data used in the 1990s, this study argues that the transition period of contemporary China should be selected. First, rapid urbanization is the main feature of contemporary China; the nation's urbanization rate reached a $50 \%$ turning point in 2011. Since then, the growth rate of urbanization declined, which means that the growth rate of rural-to-urban migrants might also decline. This is an important transition period worthy of more in-depth analysis. Secondly, policy changes related to migration and urbanization also gesture to the importance of this period. In order to promote the free migration of labor, China relaxed urban household registration restrictions after the reform and opening-up, especially in 2009, when other cities imitated Shanghai's residence permit system; in 2016, the agricultural transfer population was allowed to register as urban households, except for in several megacities. At the same time, policies on rural development also improved. After seven years of pilot exploration since the new village construction's initial proposal, the "Beautiful Village" plan was implemented in 2012. In summary, the political, economic, and social environments for rural development, as well as peasant migration, were in a typical transitional period between 2011 and 2016. This study examines the impact of political capital on peasant migration behavior, and it is unique as it uses a survey carried out with the help from local governments between September 2013 and March 2014.

In this context, we chose Xinxiang City in Henan Province as our case study location. The main reason for this is that Henan is a typical populous agricultural province in China and is representative of China's agricultural society. The contradiction between the large population size and its little to no development is particularly evident. Xinxiang City is located south of the Yellow River, in the northern part of Henan Province. It is also adjacent to the provincial capital Zhengzhou. Xinxiang City has always been an important source of food production in Henan Province. According to the Xinxiang Statistic Year Book 2013, in 2012, the sown area of grain crops in Xinxiang reached 623.06 thousand hectares, accounting for $6.23 \%$ of total amount of Henan Province, ranking 6th of 18 cities across the province. At the end of 2013, the total population of Xinxiang was 6.004 million, of which the permanent population was 5.67 million, and the urbanization rate increased from $44.69 \%$ in 2012 to $46.07 \%$ in 2013 . The Government of Xinxiang City issued a series of policy documents focusing on new village construction. In addition, in terms of services and management, the Government introduced a household registration policy for peasants in new rural communities. In terms of protecting the employment and development of peasants, the transfer of rural land contractual management rights and the construction of industrial agglomeration areas are encouraged. 
We carried out the survey with the help of local governments. The questionnaire combines stratified sampling and random sampling methods. The samples are stratified according to the administrative region, and then stratified according to the age and income of respondents. Random sampling is adopted in different layers by issuing the questionnaire to different peasants. In total, 1120 questionnaires were issued with 841 valid responses collected. The target population of this research is peasants who now live in the countryside of the Xinxiang region. We note that $80.86 \%$ of the survey respondents were male. This is generally representative of the population, as men are usually the leaders of households in traditional Chinese families. Similarly, the main laborers of these households are 31-60-year-old peasants, representing $61.07 \%$ of the respondents in our survey. This also reflects their critical position as the mainstay figure in household decisions related to migration.

\subsection{Two Logit Regression Models and Variables}

To analyze the impact of political capital on peasant migration behavior, some important factors should be defined, such as the dependent variable, migration behavior; the explanatory variable, political capital; and several other important variables from the perspective of the household.

In the survey, the following question was asked to obtain peasants' migration behavior: where will you live in the next two years? Choices are cities (including the capital city, county, and town), new villages, and old villages. Following our literature research and theory arising from these answers, this paper analyzes the determinants affecting peasants' rural-urban migration behavior decisions taking into account four aspects: (1) human capital, including education and working experience; (2) economic capital, including land capital and income; (3) political capital, which mainly refers to "whether your family have party members and cadres"; and (4) some control variables, such as the residential location, the individual characteristic of respondents, the number of members in a peasant's family, etc. The definitions of variables can be found in Table 1.

The dependent variable is the discrete data. Omitting several missing case data, 690 cases were inputted into the model. Due to the characteristics of variables involved in the research, this paper mainly used a binary logistic model and a multinomial logistic model to analyze the data. To minimize heteroscedasticity among the independent variables, logarithmic transformation was performed on all continuous variables during the construction of the model. In order to assess the impact of these variables more easily, especially political capital on migration behavior between countryside and city, this study established three models:

Model 1 is:

$$
\begin{aligned}
\operatorname{logit}\left(P_{1}\right) & =\ln \frac{p(Y=1 \mid X)}{1-p(Y=1 \mid X)} \\
& =\beta_{0}+\left[\beta_{1} \text { EducationF }+\beta_{2} \text { WorkOut }\right]+\beta_{3} \text { Party } M \\
& +\left[\beta_{4} \ln \text { DisCounty }+\beta_{5} \ln \text { DisCity }+\beta_{6} \text { Gender }+\beta_{7}\right. \text { Age } \\
& \left.+\beta_{8} \text { Education }+\beta_{9} \text { Hsize }+\beta_{10} \text { House }+\beta_{11} \text { StatusS }\right]
\end{aligned}
$$

Model 2 is:

$$
\begin{aligned}
\operatorname{logit}\left(P_{2}\right)= & \ln \frac{p(Y=1 \mid X)}{1-p(Y=1 \mid X)} \\
& =\beta_{0}+\left[\beta_{1} \ln \text { AreaH }+\beta_{2} \ln \text { AreaC }+\beta_{3} \ln \text { IncomeH }+\beta_{4} \ln \text { Income A }\right] \\
& +\beta_{5} \text { Party } M+\left[\beta_{6} \ln \text { DisCounty }+\beta_{7} \ln \text { DisCity }+\beta_{8} \text { Gender }+\beta_{9}\right. \text { Age } \\
& \left.+\beta_{10} \text { Education }+\beta_{11} \text { Hsize }+\beta_{12} \text { House }+\beta_{13} \text { StatusS }\right]
\end{aligned}
$$


Model 3 is:

$$
\begin{aligned}
\operatorname{logit}\left(P_{3}\right) & =\ln \frac{p(Y=1 \mid X)}{1-p(Y=1 \mid X)} \\
& =\beta_{0}+\left[\beta_{1} \text { EducationF }+\beta_{2} \text { WorkOut }\right]+\left[\beta_{3} \ln \text { AreaH }+\beta_{4} \ln \text { AreaC }\right] \\
& \left.+\beta_{5} \ln \text { IncomeH }+\beta_{6} \ln \text { Income }\right]+\left[\beta_{7} \text { PartyM }\right] \\
& +\left[\beta_{8} \ln \text { DisCounty }+\beta_{9} \ln \text { DisCity }+\beta_{10} \text { Gender }+\beta_{11}\right. \text { Age } \\
& \left.+\beta_{12} \text { Education }+\beta_{13} \text { Hsize }+\beta_{14} \text { House }+\beta_{15} \text { StatusS }\right]
\end{aligned}
$$

where $p(Y=1 \mid X)$ represents the probability of occurrence of event $Y=1$ given the vector $X$. The odds are the ratio of the occurrence probability to the non-occurrence probability, i.e.,

\begin{tabular}{|c|c|}
\hline Variables & Definition of Variables \\
\hline & Dependent Variable \\
\hline \multirow{5}{*}{ MigB } & The location where the peasant's household will settle \\
\hline & Binary variable: city $=1$, countryside $=0$ \\
\hline & Multi-category variable: cities $=2$, new village $=1$, old village $=0$ \\
\hline & Explanatory variable \\
\hline & Human capital \\
\hline & $\begin{array}{l}\text { The highest education level of peasant household members; junior high school, } \\
\text { primary school and below }=1 \text {, senior high school = 2, secondary school, college, }\end{array}$ \\
\hline EducationF & $\begin{array}{l}\text { bachelor's and graduate }=3 \text {. In multinomial logit model, generate three dummy } \\
\text { variables: EF_1 (if EducationF }=1, \mathrm{EF} 11=1, \text { or EF_1 }=0), \mathrm{EF} 22 \text { (if EducationF }=2 \text {, } \\
\qquad \mathrm{EF} \_2=1, \text { or EF_2 }=0 \text { ), and EF_3 (if EducationF }=3, \mathrm{EF} \_3=1, \text { or EF_3 }=0 \text { ). }\end{array}$ \\
\hline \multirow[t]{2}{*}{ WorkOut } & $\begin{array}{l}\text { Percentage of household members who work outside; the value is "number of } \\
\text { individuals working out of countryside/the total number of individuals in } \\
\text { the household". }\end{array}$ \\
\hline & Economic capital \\
\hline AreaH & $\begin{array}{c}\text { Housing area of peasant household (square meters); natural } \\
\text { logarithm transformation. }\end{array}$ \\
\hline AreaC & $\begin{array}{c}\text { Cultivated land area of peasant household (square meters); natural } \\
\text { logarithm transformation. }\end{array}$ \\
\hline IncomeH & Net income of peasant household (CNY); natural logarithm transformation. \\
\hline \multirow[t]{2}{*}{ IncomeA } & $\begin{array}{c}\text { Net agricultural income of peasant household (CNY); natural } \\
\text { logarithm transformation. }\end{array}$ \\
\hline & Political Capital \\
\hline $\mathrm{P}$ and $\mathrm{C}$ & $\begin{array}{l}\text { Have party members and cadres in the household: yes }=1, \text { no }=0 . \\
\text { Control variables }\end{array}$ \\
\hline DisCounty & Distance from village to county (kilometers); natural logarithm transformation. \\
\hline DisCity & Distance from village to city (kilometers); natural logarithm transformation. \\
\hline Gender & Dummy variable, male $=1$, female $=0$ \\
\hline Age & Age of respondents. \\
\hline Education & The education level of respondents; the value assignment is same as EducationF. \\
\hline Hsize & Number of individuals in a farmer household. \\
\hline House & Number of floors in a farmer's house. \\
\hline StatusS & Relative socioeconomic status, measured by durable consumer goods numbers. \\
\hline
\end{tabular}
the occurrence ratio, and its formula is:

$$
\text { odds }=\frac{p(Y=1 \mid X)}{1-p(Y=1 \mid X)}
$$

Table 1. Definitions of variables.

In the binary logistic model, a meaningful and essential explanatory parameter is the odds ratio (OR). OR is used to compare the odds of two groups, which is the ratio of odds of two consecutive events. The OR value reflects the influence of the independent variable on the dependent variable. This paper utilizes STATA 15.0 to estimate the model.

In addition, in order to test the different reasons for peasants' migration choices between new villages and cities, a multinomial logistic model is utilized in this research (see Model 4). 
Model 4 is:

$$
\begin{aligned}
\operatorname{logit}\left(\frac{p(Y=i \mid X)}{p(Y=0 \mid X)}\right) & =\ln \frac{p(Y=i \mid X)}{p(Y=0 \mid X)} \\
& =\beta_{0}+\left[\beta_{i 1} E F \_2+\beta_{i 2} E F \_3+\beta_{i 3} \text { WorkOut }\right] \\
& +\left[\beta_{i 4} \ln \text { AreaH }+\beta_{i 5} \ln \text { AreaC }+\beta_{i 6} \ln I n c o m e H+\beta_{i 7} \ln I \text { Income } A\right] \\
& +\left[\beta_{i 8} \text { PartyM }\right]+\left[\beta_{i 9} \ln \text { DisCounty }+\beta_{i 10} \ln \text { DisCity }\right]
\end{aligned}
$$

where $p(Y=0 \mid X)$, or the reference group, represents the probability of occurrence of the event $\mathrm{Mig} W=0$ given the vector $\mathrm{X} . p(Y=i \mid X)$ represents the probability of occurrence of the event $M i g W=i$ given the vector $X$. For multi-categorical explanatory variables such as $E d u F$ and Edu, a value of 0 is set as the reference group. This paper utilizes STATA 15.0 to estimate the model.

\section{Results and Interpretations}

According to the research design, this study will examine the impact of political capital on peasant households' migration behavior in two steps. The results are summarized in the following three parts.

\subsection{Key Factors for Migration to Cities}

Rural-to-urban migration is an important decision for a peasant household; thus, this research estimates the key factors of this migration from the perspective of a given household. A binary logistic model is adopted to analyze the effect of household capital. Table 2 presents the results of binary logistic regression analysis of migration behavior with binary dependent variables. The definition of the dependent variable in Models 1-3 is: 1 if the migration destination is a town, county, or city; 0 if the migration destination is an old or new village. From the overall test results of all three models (see Table 2), Model 3 is the most effective in general. In Model 3, log likelihood is -208.396 and Pseudo $\mathrm{R}^{2}$ is 0.190 , indicating that the model fits well; McFadden $\mathrm{R}^{2}$ is 0.190 and Count $\mathrm{R}^{2}$ is 0.878 , indicating that the model has a good interpretation ability and a high prediction accuracy.

As presented in Table 2, political capital has a significant effect on peasant households' migration behavior. Peasant households with party members and cadres are the most likely group to migrate. In Model 1 and Model 2 (see Table 2), variable P and C has been put in separately to model the human capital of peasant households and the economic capital of peasant households; the results show that the influence of $\mathrm{P}$ and $\mathrm{C}$ is always the highest. In these two models, $\mathrm{P}$ and $\mathrm{C}$ has a significantly positive effect on the migration behavior of peasant households at the level of 0.05, with the highest OR values being 2.581 and 2.670. The same situation happened in Model 3 when all the variables were considered. P and $C$ have a significantly positive effect on migration behavior at the level of 0.05 , with the highest OR value being 2.684. Migration is a decision made by the entire household. Since China's rural areas are self-governing under the leadership of the Communist Party of China, peasant families with party members and cadres will have more opportunities to obtain relevant information. This means they are more likely to migrate.

In general, the impact of economic capital is higher than human capital in terms of peasant households' migration behavior, indicating that land assets have a strong 'pull' force that affects migration decisions. The variable EducationF has no significant effect on migration behavior in Model 1 or Model 3. On the contrary, variable AreaC has a significantly negative effect on migration behavior at the 0.01 level in Model 2 and Model 3 . Furthermore, the variable IncomeH has a positive significant effect on migration behavior at the 0.1 level in Model 2, but when more variables are contained in the model, the effect of IncomeH becomes non-significant. From this change in the model's result, the important 'pull' force of land assets of peasant households is evident. 
Table 2. Influencing factors on peasants' migration behavior (binary logistic model).

\begin{tabular}{|c|c|c|c|c|c|c|}
\hline & \multicolumn{2}{|c|}{ Model 1} & \multicolumn{2}{|c|}{ Model 2} & \multicolumn{2}{|c|}{ Model 3} \\
\hline & Coef. & Odds & Coef. & Odds & Coef. & Odds \\
\hline \multicolumn{7}{|c|}{ Human Capital } \\
\hline EducationF & 0.208 & 1.231 & & & 0.322 & 1.380 \\
\hline WorkOut & 0.315 & 1.371 & & & 0.346 & 1.413 \\
\hline \multicolumn{7}{|c|}{ Economic Capital } \\
\hline $\ln$ AreaH & & & -0.346 & 0.708 & -0.456 & 0.634 \\
\hline $\ln$ AreaC & & & $-0.966^{* * *}$ & 0.380 & $-1.029^{* * *}$ & 0.357 \\
\hline lnIncomeH & & & 0.414 * & 1.513 & 0.336 & 1.400 \\
\hline lnIncomeA & & & -0.05 & 0.951 & -0.033 & 0.967 \\
\hline \multicolumn{7}{|c|}{ Political Capital } \\
\hline $\mathrm{P}$ and $\mathrm{C}$ & $0.948^{* *}$ & 2.581 & 0.982 ** & 2.670 & $0.987^{* *}$ & 2.684 \\
\hline \multicolumn{7}{|c|}{ Control Variables } \\
\hline lnDisCounty & $-0.523^{* * *}$ & 0.593 & $-0.448^{* *}$ & 0.639 & $-0.496^{* *}$ & 0.609 \\
\hline lnDisCity & 0.191 & 1.21 & 0.269 & 1.309 & 0.314 & 1.369 \\
\hline Gender & 0.447 & 1.564 & 0.557 & 1.746 & 0.58 & 1.786 \\
\hline Age & -0.005 & 0.995 & -0.001 & 0.999 & -0.006 & 0.994 \\
\hline Education & $0.558^{* *}$ & 1.748 & $0.503^{* *}$ & 1.654 & 0.404 * & 1.498 \\
\hline HSize & $-0.606^{* * *}$ & 0.546 & $-0.493^{* * *}$ & 0.611 & $-0.474^{* * *}$ & 0.623 \\
\hline House & 0.264 & 1.302 & -0.076 & 0.926 & -0.030 & 0.970 \\
\hline StatusS & $0.248^{* * *}$ & 1.281 & $0.247^{* * *}$ & 1.280 & $0.233^{* * *}$ & 1.263 \\
\hline _cons & -2.98 & 0.051 & -5.534 & 0.004 & -5.422 & 0.004 \\
\hline Number of obs & \multicolumn{2}{|c|}{689} & \multicolumn{2}{|c|}{688} & \multicolumn{2}{|c|}{688} \\
\hline LR chi ${ }^{2}$ & \multicolumn{2}{|c|}{$76.74^{* * *}$} & \multicolumn{2}{|c|}{$94.20^{* * *}$} & \multicolumn{2}{|c|}{$97.74 * * *$} \\
\hline Log likelihood & \multicolumn{2}{|c|}{-219.028} & \multicolumn{2}{|c|}{-210.168} & \multicolumn{2}{|c|}{-208.396} \\
\hline Pseudo $\mathrm{R}^{2}$ & \multicolumn{2}{|c|}{0.149} & \multicolumn{2}{|c|}{0.183} & \multicolumn{2}{|c|}{0.190} \\
\hline McFadden's $\mathrm{R}^{2}$ & \multicolumn{2}{|c|}{0.149} & \multicolumn{2}{|c|}{0.183} & \multicolumn{2}{|c|}{0.190} \\
\hline Cragg and Uhler's $\mathrm{R}^{2}$ & \multicolumn{2}{|c|}{0.200} & \multicolumn{2}{|c|}{0.243} & \multicolumn{2}{|c|}{0.251} \\
\hline McKelvey and Zavoina's $\mathrm{R}^{2}$ & \multicolumn{2}{|c|}{0.322} & \multicolumn{2}{|c|}{0.333} & \multicolumn{2}{|c|}{0.352} \\
\hline Count $\mathrm{R}^{2}$ & \multicolumn{2}{|c|}{0.877} & \multicolumn{2}{|c|}{0.884} & \multicolumn{2}{|c|}{0.878} \\
\hline
\end{tabular}

Notes: * Statistically significant at the 0.1 level; ${ }^{* *}$ statistically significant at the 0.05 level; ${ }^{* * *}$ statistically significant at the 0.01 level.

Among control variables, the DisCounty and HSize had significantly negative effects on migration behavior at the 0.05 level and 0.01 level in Model 3, while education and StatusS had significantly positive effects on migration behavior at the 0.1 level and 0.01 level. This result shows that: (1) those peasant households who have higher socioeconomic status in their current place of residence are capable of migrating out of the countryside; (2) when the respondents have higher education or a smaller family size, there will be a greater tendency to migrate from the countryside; and (3) peasants living around the county, not around the city, are more inclined to prefer settling in cities.

\subsection{The Reason for Choices between Cities and New Village for Peasants}

The above findings show that peasant households with political capital tend to move to cities, which is different from results in previous studies. This is because previous studies show that peasants with political capital are more inclined to increase their housing investment in rural areas [42]. Nevertheless, our study selects the multinomial logit model to analyze the migration behavior options between cities and new villages with better conditions. The new village is a settlement built in rural areas with the same social network as a traditional village but with a superior living environment. If peasant households with political capital are more inclined to stay in local rural areas and increase housing investment, will a new village be a good choice? The question will be examined with an MNL model. The explanatory variable in MNL is migration behavior (short for MigB), where $M i g B=0$ indicates that peasant households still choose to live in the traditional village, $\operatorname{Mig} B=1$ indicates that peasant households choose to live in the new village, and $M i g B=2$ indicates that peasant households choose to migrate to cities. 
According to Hausman's test results, each option of dependent variables is independent, and the possibility of selecting a certain option is independent of the existence of other choices but only related to the control group. This satisfies the IIA (independence of irrelevant alternatives) assumption, meaning that it is appropriate to use the multinomial logit model to analyze the influencing factors for peasants' migration behavior. From the overall test results of the model (see Table 3), log likelihood is -523.388 and Pseudo $R^{2}$ is 0.212 , indicating that the model fits well; McFadden $R^{2}$ is 0.212 , Cox and Snell $R^{2}$ is 0.336 , Nagelkerke $R^{2}$ is 0.393 , Count $R^{2}$ is 0.656 , and the correct percentage of the model's overall prediction is $67.0 \%$, indicating that the model has a better interpretation ability and a higher prediction accuracy. Therefore, from a holistic perspective, the model has a good degree of fit and a high degree of credibility.

According to the results above, compared with continued living in a traditional village, the peasant households with political capital have a significantly higher possibility of migrating to cities, but there is no obvious willingness to migrate to new villages. This also shows that farmers with political capital tend to leave rural areas; even new villages dominated by state policies and with better living conditions will not change their minds. From Table 3, we can see that political capital is important in migration to cities but not to new villages. There are three analyses related to this finding: (1) the variable P and C, which represents political capital, has no significant effect on the possibility of migration to a new village but has a significantly positive impact on the probability of moving to city at a level of 0.01 . From the perspective of the relative risk ratio, the possibility of peasant families with party members and cadres moving to the city is 2.991 times the possibility of peasant families without party members cadres moving. The influence of political capital on peasant household migration to cities is both significant and important, but it has no significant impact on local migrations. (2) For economic capital variables, compared to living in a traditional village, IncomeH has a negative effect on the possibility of moving to a new village at a 0.01 level, and $A r e a C$ has a negative impact on the possibility of moving to cities at a level of 0.01 . For every additional unit of a peasant household's annual income, the possibility of moving to a new village is reduced by $38 \%$, indicating that relatively poor peasant families have a greater possibility of moving into a new village. The important factor limiting migration to cities is the cultivated land the peasant families hold. For each additional unit of cultivated land, the probability of moving into a city is reduced by $72.4 \%$. (3) In variables of human capital, compared to living in a traditional village, variable $E F \_2$ has a significantly negative effect on the possibility of moving to new villages on a 0.1 level, while $E F \_3$ has no significant influence; the WorkOut variable has a significantly positive effect on the possibility of moving to new villages on a 0.1 level. All factors in human capital have no significant influence on the probability of moving to cities.

Since political capital does not lead to a higher possibility of peasant households moving to new villages, what is the biggest concern regarding peasant households' migration in local rural areas? This study investigates the subjective reasons for peasants moving to the new villages and, from the survey results, it can be seen that the most subjective concerns of peasants are economic in nature. On the contrary, the attitudes of peasants regarding political-related factors do not show an appreciable difference (see Table 4). First, the "cost of building/purchasing a house in a new village" is the most concerning issue for peasants, with the highest average score (3.90) and a small standard deviation (1.36). This result shows that, due to the cost of acquiring new homes being a major economic expenditure for Chinese families, it has also become an important issue that is highly valued by peasants households when deciding whether to move to a new village. Second, the "satisfaction of government compensation" is also a key issue for peasants to consider. The average score of this issue given by respondents was 3.83, with a standard deviation of 1.31 , which is smaller than other reasons except for one economic-related reason. This result shows that, during the process of the Government's marketing of new village construction, peasants have generally believed that the Government should make reasonable compensations. In the context of rural grassroots autonomy under the leadership of the Chinese Communist 
Party, the marketing and implementation of various policies mainly rely on party members and cadres. Therefore, in terms of the acceptance of policies, party members and cadres have advantages. However, their political capital advantage is not important in migration to new villages. Due to the fact that living is the most important thing for peasant families, they generally have subjective initiatives to learn policies when deciding whether to move to a new village. Additionally, in this process, there is little difference between peasant families with political capital and those without such capital.

Table 3. Different influencing factors of peasants' migration behavior (multinomial logit model).

\begin{tabular}{|c|c|c|c|c|}
\hline & \multicolumn{2}{|c|}{ P (to New Village) } & \multicolumn{2}{|c|}{ P (to Cities) } \\
\hline & Coef. & RRR & Coef. & RRR \\
\hline \multicolumn{5}{|c|}{ Human Capital } \\
\hline EF_2 & $-0.487 *$ & 0.615 & -0.406 & 0.666 \\
\hline EF_3 & 0.141 & 1.152 & 0.508 & 1.663 \\
\hline WorkOut & $0.748^{*}$ & 2.112 & 0.732 & 2.078 \\
\hline \multicolumn{5}{|c|}{ Economic Capital } \\
\hline $\ln$ AreaH & 0.312 & 1.366 & -0.289 & 0.749 \\
\hline $\ln$ AreaC & -0.316 & 0.729 & $-1.286^{* * *}$ & 0.276 \\
\hline lnIncomeH & $-0.478^{* * *}$ & 0.62 & 0.084 & 1.088 \\
\hline InIncomeA & 0.203 & 1.225 & 0.081 & 1.085 \\
\hline \multicolumn{5}{|c|}{ Political Capital } \\
\hline $\mathrm{P}$ and $\mathrm{C}$ & 0.143 & 1.154 & $1.096^{* *}$ & 2.991 \\
\hline \multicolumn{5}{|c|}{ Control Variables } \\
\hline lnDisCounty & $0.285 *$ & 1.33 & -0.294 & 0.745 \\
\hline lnDisCity & $2.153^{* * *}$ & 8.615 & $1.713^{* * *}$ & 5.544 \\
\hline Gender & $0.986^{* * *}$ & 2.679 & $1.136^{* * *}$ & 3.116 \\
\hline Age & -0.01 & 0.99 & -0.01 & 0.99 \\
\hline E_2 & $0.553^{* *}$ & 1.738 & $0.709^{* *}$ & 2.033 \\
\hline E_3 & 0.641 & 1.898 & $1.382 * *$ & 3.982 \\
\hline HSize & -0.034 & 0.966 & $-0.451 * * *$ & 0.637 \\
\hline House & $-0.659 * * *$ & 0.518 & -0.387 & 0.679 \\
\hline StatusS & $0.068 *$ & 1.07 & $0.264^{* * *}$ & 1.302 \\
\hline _cons & -3.613 & 0.027 & -6.612 & 0.001 \\
\hline Number of obs & \multicolumn{4}{|c|}{688} \\
\hline LR chi ${ }^{2}$ & \multicolumn{4}{|c|}{$281.62^{* * *}$} \\
\hline Log likelihood & \multicolumn{4}{|c|}{-523.388} \\
\hline Pseudo $R^{2}$ & \multicolumn{4}{|c|}{0.212} \\
\hline McFadden's $\mathrm{R}^{2}$ & \multicolumn{4}{|c|}{0.212} \\
\hline Cox and Snell $\mathrm{R}^{2}$ & \multicolumn{4}{|c|}{0.336} \\
\hline Nagelkerke $\mathrm{R}^{2}$ & \multicolumn{4}{|c|}{0.393} \\
\hline Count $\mathrm{R}^{2}$ & \multicolumn{4}{|c|}{0.656} \\
\hline
\end{tabular}

Notes: * Statistically significant at the 0.1 level; ${ }^{* *}$ statistically significant at the 0.05 level; ${ }^{* * *}$ statistically significant at the 0.01 level. The reference group is $\operatorname{MigB}=0$, including the cases whose migration behavior is an old village.

Table 4. The characteristics of reasons for living in a new countryside.

\begin{tabular}{|c|c|c|c|c|}
\hline \multirow{2}{*}{ Questions } & \multirow{2}{*}{ Attribute } & \multicolumn{3}{|c|}{ Score of Peasants' Answers } \\
\hline & & Average & Median & Standard Deviation \\
\hline 1. Cost of building/purchase a house in a new village & economic & 3.90 & 4 & 1.36 \\
\hline 2. Satisfaction with government compensation & political & 3.83 & 4 & 1.31 \\
\hline $\begin{array}{l}\text { 3. Better infrastructure for water, electricity, heating, and } \\
\text { gas in new village }\end{array}$ & social & 3.80 & 4 & 2.52 \\
\hline 4. More job opportunities and higher income & economic & 3.74 & 4 & 2.17 \\
\hline 5. Cost of living and other expenses in new village & economic & 3.57 & 4 & 1.26 \\
\hline 6. House living area in new village & social & 3.57 & 4 & 1.49 \\
\hline 7. Better medical security and pension insurance & social & 3.49 & 4 & 1.45 \\
\hline 8. More convenience in life and work in new village & social & 3.41 & 4 & 1.42 \\
\hline 9. More convenience in streets and roads in new village & social & 3.38 & 3 & 1.41 \\
\hline 10. Neighborhood relations in new village & social & 2.84 & 3 & 1.31 \\
\hline
\end{tabular}




\subsection{Whether Political Capital Has a Significant Influence on Peasants' Migration Behavior}

It can be seen from the above two steps of estimation that the peasant families with political capital do have a greater possibility of migrating to urban areas; on the contrary, peasant families with less political capital tend to stay where they are. The reason for this phenomenon is due to the Chinese Government's commitment to promoting the transformation of a socialist market economy and to implement a series of urbanization policies that provide opportunities for rural migrants, especially those with political capital, and ultimately change the transitional pathway of political capital.

With control of the socialist market economic system, the Government has tighter regulation of the market, which makes it more difficult to seek rent in local rural areas. In the early stage of the socialist market economy, the lack of public participation and supervision fosters rural grassroots autonomous organizations. Rural grassroots are the agents entrusted by the public power of rural collective organization and have greater discretion over rural local developments in the political hierarchy. Therefore, the political actors of rural grassroots collective organizations can gain and strengthen their local comparative advantage through this power, thus establishing local political connections to further improve their local positional power $[1,43]$. Rent seeking is common due to the lack of supervision, as well as political actors' effects on rural planning and development. However, with the socialist market economy transformation, especially the improvement in public participation and supervision mechanisms, the cost of rent-seeking activities has increased. Although political actors are still policymakers for local development, public participation increases day by day in many village decisions, and village cadres elected through village collective organizations are also subject to more supervision from the villagers. Agents struggle to strengthen their local influence through the power of delegation. Since political actors cannot have absolute discretion over rural development, they attempt to establish political connections with other agents through the identity of agents granted collective public power; political connections with higher-level agents in the political hierarchy represent powerful advantages that help one enter higher-level cities.

The transfer of political capital has changed due to the characteristics of political capital and increasingly difficult rent-seeking activities. Political capital is a scarce resource rooted in social relations and political institutions. It is closely related to human and economic capital, so its transfer needs to rely on agents $[1,44,45]$. For village collective organizations, when the relationship between the agent and the power granted by the village collective organization changes, a new pathway is needed to transfer political capital. There are two stages in this process.

First, from the 1980s to 1990s, township enterprises were the main agents transforming political capital into economic capital, which mainly occurred in rural areas. The household registration reform had just started, the urban-rural dual structure was obvious, and there was no efficient policy to support migrant workers. However, there were strong policies in place to promote the development of township enterprises. During this period, the township enterprises formed collectively by the village participated in the market economy. As the agent of collective village power, the organization has important decision-making power in township enterprises and rural development. The village cadre, the political actor of the organization, can strengthen political power and political connections accordingly. Therefore, peasant families with political capital have access to better employment opportunities, higher income, and a broader network in their own township enterprises. At the same time, they make these advantages safer. Of course, farmers with economic capital are also willing to obtain and accumulate political capital, thereby further increasing their employment opportunities, raising wages, and expanding their local social network. This supports previous studies that found that peasant households with political capital did not tend to migrate to cities in the 1990s [27,39].

Second, after 2000, the transformation of political capital required urban agents, so farmers with political capital were more inclined to enter cities. The socialist market economic system has been refined, and the household registration reform supported free- 
flowing labor; at the same time, the rent-seeking activities of power in village collectives became increasingly difficult. Therefore, moving to cities became the primary way of transferring political capital to economic capital $[44,45]$. Grassroots governance in China's rural areas is up to villagers' autonomy under the leadership of the Chinese Communist Party of China. In the process of poverty alleviation and rural revitalization to promote production and increase farmers' income, village party members and cadres are often the first to participate in skills and technology training, policy learning, higher education, and other activities organized by the Government. Even rural party members and cadres need to learn and train many times to ensure that they can carry out propaganda activities accurately. Therefore, they have more opportunities than ordinary farmers to obtain relevant information, expand their social networks, and establish contacts with urban agents. As a result, in the process of migrating to cities, a peasant family with political capital obtains a comparative advantage of working and living in a city through the political connection established with the city agent; these are advantages not available to peasant families without political capital. Political capital and political connections result in more employment opportunities and higher wages through a city's market. In summary, under the current political and economic environment, peasant households with political capital are more inclined to migrate to cities.

\section{Conclusions and Implications}

In contrast to conventional research interests regarding the influence of economic factors and social factors on migration behavior, this study focuses on the influence of peasant households' political capital on migration behavior in the context of the rapid urbanization witnessed in China in the recent decades. To achieve the goal of detecting whether political capital is an important factor in the migration behavior of peasant households, we used a survey in Xinxiang City in Henan province to obtain information about political capital, human capital, and economic capital. Following our research design, a binary logistic model and a multinomial logistic model were used to examine the influence of political capital.

This research argues that a peasant household with political capital has a greater possibility of migrating to cities, but this has no obvious effect on staying in local rural areas. This is different from previous studies that focus on human capital and economic capital $[11,16]$. This paper has certain academic implications for enriching our understanding of migration. However, the case selection of traditional agricultural areas does not reflect all situations in China, although traditional agricultural areas form a significantly representative part of the country. Compared with previous research, the time of the survey and questionnaire selected in this study reflects a specific historical period of economic and environmental development and transition to a political environment favoring migration. This point in time serves a "the turning point as China's urbanization rate exceeds 50\%", which is nevertheless representative of China's overall economic growth. However, research pertaining to cross-section analyses is still inadequate. Thus, comparative research into different historical periods and testing in follow-up events is still necessary.

There are three issues worthy of attention. First, although this study and previous studies both believe that the identity of party members and cadres is very important and allows farmers to accumulate political capital [24,26], our approach argues that political capital can significantly and actively promote rural-to-urban migration of farmers, which is different from previous studies. Some studies suggest that political capital has no or even a negative impact on rural-to-urban migration [27,39], but there is a consensus that political capital affects farmers' migration decisions $[2,16,20]$. The reason behind the difference is that the data in those studies are national data from the 1990s. Due to tremendous changes in the political and economic environment brought about by the socialist market economy reform, current rent-seeking activities in rural areas are much more difficult than they were prior to 2000. On the contrary, because of improvements in public participation and supervision mechanisms in rural China, political actors have established political 
connections with higher level agents through the public power granted by village collective organizations. This power then becomes a comparative advantage when entering cities. Political capital can be converted to better employment opportunities and higher income in cities. Existing research has fully proven that political capital can influence employment and generate higher income [3,6], and increases in income can affect migration from rural to urban areas [5]. Therefore, in theory, the impact of political capital on rural-to-urban migration behavior should be positive and significant. Contrary to previous studies, this study used survey data from traditional agricultural areas in China in 2014. On the one hand, this is a period characterized by a more mature socialist market economic system and a modernized form of governance. On the other hand, the choice of traditional agricultural areas also makes the case area more homogeneous regarding social, economic, and cultural backgrounds. Thus, our data present a better illustration of the characteristics of China's market economy based on small-scale peasant economy.

Second, existing studies have confirmed that political capital affects employment opportunities and income $[3,4,24,46]$, and, in turn, whether and where farmers migrate $[24,27]$. Although both this study and previous studies maintain that political capital creates other advantages $[4,24,25]$, this research argues that, with the improving governance capabilities of the Chinese Government, the political capital transfer pathway to higher wages has changed. In rural China, policies are communicated to peasants through Communist party organizations and village self-governing organizations. Therefore, the status of the party member and cadre is hugely important for peasants in accepting new policies and keeping pace with new changes. Meanwhile, political capital could increase peasants' access to new resources, which will help them accumulate political connections, thereby indirectly increasing the accumulation of their own human capital and enhancing their ability to obtain economic capital. We argue that giving more opportunities to take part in the practice of rural development and creating initiatives to raise more awareness regarding policies may be helpful in increasing the efficiency of urbanization.

Third, traditional Chinese urbanization research practices and theories pay more attention to efficiency [47]. However, this research argues that no matter how much political capital a farmer has, they should be treated equally. Existing studies have shown that inequality (for example, unequal access to land) can cause migration crises [48], and political capital is an important driving force of inequality in China [20]. While some studies suggest that the solution to the migration crisis is to create fairer opportunities [48], this research argues that, from the perspective of fairness, improving the refined system of urbanization research is also worthy of attention for the following reasons: (1) For the equity of urbanization research, farming families with less political capital should not be ignored, due to the fact that the Chinese Government is committed to providing them with aid services. For example, China's grassroots government has carried out an extensive campaign of raising awareness of relevant policies and information, as well as providing skill training for farmers. The issue is that farmers with little political capital are not familiar with how to obtain such information. (2) From the perspective of equity, the Government can work to improve the urbanization policy system by taking into account the political capital of farmers' families. Focusing on farmers' families with less political capital, the grassroots government should strengthen their ability to obtain information through more targeted policy propaganda and skills training. (3) Equitable urbanization must fully respect the willingness of farmers' families, and treat those who want to move to cities or a new countryside differently. Of course, this is not entirely based on political capital. Farming families who voluntarily migrate to cities need training to develop specific, non-agricultural work skills, as well as catering workshops to provide the channels to information regarding social security, employment assistance, medical care, and schooling. 
Author Contributions: Conceptualization, H.S., C.F. and Y.S.; methodology, H.S.; software, H.S.; validation, H.S., Y.S. and Z.S.; formal analysis, Y.S.; investigation, H.S. and C.F.; resources, C.F.; data curation, H.S.; writing-original draft preparation, H.S.; writing-review and editing, Y.S. and Z.S.; visualization, H.S.; supervision, C.F.; project administration, C.F.; funding acquisition, C.F. All authors have read and agreed to the published version of the manuscript.

Funding: This research was funded by National Key R\&D Program of China, grant number is 2018YFD1100300.

Institutional Review Board Statement: Not applicable.

Informed Consent Statement: Not applicable.

Conflicts of Interest: The authors declare no conflict of interest.

\section{References}

1. Nee, V.; Opper, S. Political capital in a marker economy. Soc. Forces 2010, 88, 2105-2132. [CrossRef]

2. Appleton, S.; Knight, J.B.; Song, L.; Xia, Q. The Economics of Communist Party Membership: The Curious Case of Rising Numbers and Wage Premium during China's Transition. J. Dev. Stud. 2009, 45, 256-275. [CrossRef]

3. Yan, S. The changing faces and roles of communist party membership in China: An empirical analysis based on CHIPS 1988,1995 and 2002. J. Contemp. East Asia Stud. 2019, 8, 99-120. [CrossRef]

4. Wang, W.; Li, Q.; Lien, D. Human capital, political capital, and off-farm occupational choices in rural China. Int. Rev. Econ. Financ. 2016, 42, 412-422. [CrossRef]

5. Stark, O.; Taylor, J.E. Migration incentives, migration types: The role of relative deprivation. Econ. J. 1991, 101, 1163-1178. [CrossRef]

6. Cao, T.; Qian, X. Political Capital, and Household Income: Evidence from Twenty-Four Transition Countries. J. Fam. Econ. Issues 2021, 42, 151-165. [CrossRef]

7. Zhao, Y.H. Leaving the Countryside: Rural-To-Urban Migration Decisions in China. Am. Econ. Assoc. 1999, 89, 281-286. [CrossRef]

8. Philip, E.G.; Peter, D.L. Household migration: Theoretical and empirical results. J. Urban Econ. 1979, 6, $383-404$.

9. Douglas, S.M. Social Structure, Household Strategies, and the Cumulative Causation of Migration. Popul. Index 1990, 56, 3-26.

10. Fan, C.C. Interprovincial Migration, Population Redistribution, and Regional Development in China. Prof. Geogr. 2005, 57, 295-311. [CrossRef]

11. Fan, C.C. China on the Move: Migration, the State, and the Household, 1st ed.; Routledge: Oxford, UK, 2008.

12. Fleisher, B.M.; Yang, D.T. Problems of China's Rural Labor Markets and Rural-Urban Migration. Chin. Econ. 2006, 39, 6-25. [CrossRef]

13. Fan, C.S.; Stark, O. Rural-to-urban migration, human capital, and agglomeration. J. Econ. Behav. Organ. 2008, 68, 234-247. [CrossRef]

14. Hao, P.; Tang, S. Floating or settling down: The effect of rural landholdings on the settlement intention of rural migrants in urban China. Environ. Plan. A 2015, 47, 1979-1999. [CrossRef]

15. Harris, J.R.; Todaro, M.P. Migration, unemployment, and development: A two-sector analysis. Am. Econ. Rev. 1970, 60, 126-142.

16. Yang, Z.; Cai, J.; Qi, W.; Liu, S.; Deng, Y. The influence of income, lifestyle, and green spaces on interregional migration: Policy implications for China. Popul. Space Place 2017, 23, e1996. [CrossRef]

17. Ma, Z.D. Social-capital mobilization, and income returns to entrepreneurship: The case of return migration in rural China. Environ. Plan. A 2002, 34, 1763-1784. [CrossRef]

18. Wang, F.; Zuo, X. Inside China's cities: Institutional barriers and opportunities for urban migrants. Am. Econ. Rev. 1999, 89, 276-280. [CrossRef]

19. Rerat, P. The selective migration of young graduates: Which of them return to their rural home region and which do not? J. Rural Stud. 2014, 35, 123-132. [CrossRef]

20. Li, S.; Lu, M.; Sato, H. Power as a Driving Force of Inequality in China: How Do Party Membership and Social Networks Affect Pay in Different Ownership Sectors? Cesifo Econ. Stud. 2009, 55, 624-647. [CrossRef]

21. Song, S.; Zhang, K.H. Urbanization and city-size distribution in China. Urban Stud. 2002, 39, 2317-2327. [CrossRef]

22. Vendryes, T. Migration constraints and development: Hukou and capital accumulation in China. China Econ. Rev. 2011, 22, 669-692. [CrossRef]

23. Pi, J.; Zhang, P. Hukou system reforms and skilled-unskilled wage inequality in China. China Econ. Rev. 2016, 41, 90-103. [CrossRef]

24. Zhang, J.; Giles, J.; Rozelle, S. Does it pay to be a cadre? Estimating the returns to being a local official in rural China. J. Comp. Econ. 2012, 40, 337-356. [CrossRef]

25. Xia, Q.; Simmons, C. Employment and earnings of off-farm activities in rural China. China Labor Econ. 2007, 42, 57-87. (In Chinese)

26. Guo, Z.; Bernstein, P.T. The impact of elections on the village structure of power: The relations between the village committees and the party branches. J. Contemp. China 2004, 13, 257-275. 
27. Guang, L.; Zheng, L. Migration as the second-best option: Local power and off-farm employment. China Q. 2005, 181, 22-45. [CrossRef]

28. Chen, C.; Fan, C.C. China's Hukou Puzzle: Why Don't Rural Migrants Want Urban Hukou? China Rev. 2016, 3, 9-39.

29. Lu, J.; Wang, D.; Wu, L. A Review on Trajectory of Migration Policies in China: From 1949 to 2019. J. China Agric. Univ. (Soc. Sci.) 2019, 36, 120-128. (In Chinese)

30. Guan, J. A Summary of “International Symposium on Rural Labor Mobility in China”. China Rural Surv. (In Chinese). 1997, 18, 56-59.

31. Guo, D. The Change of Household Registration System, Population Mobility, and the Process of Urban-Rural Integration in New China in the Past 70 Years. Zhejiang Soc. Sci. 2019, 35, 75-84+158. (In Chinese)

32. Ahlers, A.L. Rural Policy Implementation in Contemporary China: New Socialist Countryside, 1st ed.; Routledge: Oxford, UK, 2014.

33. Liu, Y. Rural transformation development and new countryside construction in eastern. Acta Geogr. Sin. 2007, 62, 563-570. (In Chinese)

34. Long, H.; Liu, Y.; Li, X.; Chen, Y. Building new countryside in China: A geographical perspective. Land Use Policy 2010, 27, 457-470. [CrossRef]

35. Li, Y.H.; Westlund, H.; Zheng, X.Y.; Liu, Y.S. Bottom-up initiatives and revival in the face of rural decline: Case studies from China and Sweden. J. Rural Stud. 2016, 47, 506-513. [CrossRef]

36. Stepan, M.; Han, E.; Reeskenns, T. Building the new socialist countryside: Tracking public policy and public opinion changes in China. China Q. 2016, 226, 456-476. [CrossRef]

37. Tang, P. The Rise and Fall of Chinese Township Enterprises (1978-2002), 1st ed.; Beijing Institute of Technology Press: Beijing, China, 2013. (In Chinese)

38. Ma, X.; Wang, W.; Wu, X.; Huang, H. Current problems and countermeasures for the development of township enterprises. Chin. Rural Econ. 1998, 14, 21-25. (In Chinese)

39. Li, H.; Zahniser, S. The determinants of temporary rural-to-urban migration in China. Urban Stud. 2002, 39, 2219-2235. [CrossRef]

40. Zhou, L. Reflections on the Problem of Poverty Elimination in the Major Grain-producing Counties-A Case of Henan Province. Acad. J. Zhongzhou 2016, 38, 59-64. (In Chinese)

41. An, H.; Xu, J. Suggestions for Speeding up the New Urbanization Progress in the Main Grain Production Areas. Rev. Econ. Manag. 2016, 32, 136-140. (In Chinese)

42. Tian, C.; Wu, J. Social stratification, rural housing investment and rural housing stratification. China Real Estate 2018, 619, 36-45. (In Chinese)

43. Szelenyi, I. Urban Inequality under State Socialist Redistributive Economies, 1st ed.; Oxford University Press: Oxford, UK, 1983.

44. Collinson, S. The Political Economy of Migration Processes: An Agenda for Migration Research and Analysis; International Migration Institute Working Paper; International Migration Institute: Holland, The Netherlands, 2009; Volume 12. Available online: https:/ / www.migrationinstitute.org/publications/wp-12-09 (accessed on 8 December 2021).

45. Meekaew, N.; Ayuwat, D. Capital utilization for livelihoods among rural fishing migrant households in the origin area. Int. J. Eng. Technol. 2018, 7, 86-90. [CrossRef]

46. Jin, Y.; Fan, M.; Cheng, M.; Shi, Q. The economic gains of cadre status in rural China: Investigating effects and mechanisms. China Econ. Rev. 2014, 31, 185-200. [CrossRef]

47. Luo, Z.; Wan, G.H.; Zhang, X.; Li, J. Urbanization with Equity Considerations: Theory and Evidence from China. Econ. Res. 2018, 53, 89-105. (In Chinese)

48. Obeng-Odoom, F. Unequal access to land and the current migration crisis. Land Use Policy 2017, 62, 159-171. [CrossRef] 